DOI https://doi.org/10.18551/rjoas.2020-09.12

\title{
A STUDY OF ENTREPRENEURIAL ORIENTATION AND BUSINESS PERFORMANCE IN SMALL MEDIUM ENTREPRISE
}

\author{
Surriadi Berman*, Raharja Sam'un Jaja, Purnomo Margo, Muhyi Herwan Abdul \\ Business Administration, University of Padjadjaran, Bandung, Indonesia \\ *E-mail: bermansuryadi@yahoo.com
}

\begin{abstract}
The main objective of this study was to explore the role of orientation towards entrepreneurial business performance. Respondents in this study were all people in business creative industries embroidery in Bangil the 100 (one hundred) people, whether male or female, with a distribution of age, level of education, business scale and duration of the different business, data analysis using structural equation model SEM-PLS. Research findings indicate that women are proactive risk and have a significant influence on innovation, while the other variables have not had a significant relationship.
\end{abstract}

\section{KEY WORDS}

Entrepreneurial orientation, business performance, SMEs.

Small-medium enterprises (SMEs) play an essential role in every country and contribute to economic development, employment, and poverty reduction. There are several reasons why MSMEs have become benchmarks for instruments of economic growth (Machmud \& Sumawidjaja, 2020), especially in developing countries. One reason for including the support of entrepreneurship and innovation activities those promote competition and growth in labor productivity. SMEs are creative because of the flexibility and adaptability to the changing market higher. The majority of SMEs provide the highest contribution to job creation, in addition to the failure of SMEs cannot be avoided (Imanto, Prijadi, \& Kusumastuti, 2019).

However, many studies have examined the literature related to SMEs and their contribution to economic growth in a country, empirical research on the creative industries for example, in the field of fashion, media, movies, music, and advertising and related to the emergence of the uniqueness of the local culture about the emergence of local cultural uniqueness (Helmy, Adawiyah, \& Banani, 2019). At the same time, Zheng \& Callaghan (2018) stated that cultural values held by the people and organizations become part of the culture and reflect national culture. Moreover, according to Rofaida, Suryana, \& Yuliawati (2019), national culture can describe the level of entrepreneurial an organization through which cultural values become part of the community and through the organizations that implement cultural (Ikhsan, Almahendra, and Budiarto, 2017).

Few studies examine the influence of organizational culture on entrepreneurship, but very few have examined how both entrepreneurship and influence organizational innovation. This innovation activity is about starting a new way of product, service, marketing, and technology and challenging to replicate. Therefore, innovation plays an essential role in spurring business performance (Wiklund \& Shepherd, 2005), especially the local creative industry.

This business performance reflects the ability to increase customer interest in buying their products. Thus, managers need to increase organizational innovation through all efforts by providing regular training for employees, creating new products, modifying new products, developing new ideas, and supporting employee initiatives. In this case, entrepreneurial orientation, as well as innovation in general, is required to produce specific ideas in the context of the local creative industry supporting tourism. Based on the ideas of creative industries that exist outside the context of developing countries, we revisit the urgency of such an industry in Indonesia. Indonesia has been recognized as one of the most vibrant and fast-growing developing countries (Games, 2019). Siregar et al. (2020) argue that Indonesia 
has a different context with other developing countries, such as South Korea, Japan, and China, which have gone further in developing creative industries and are categorized as high-income countries in Asia.

In line with these arguments, Richardson (2019) also argues that there are two main aspects of implementing a creative economy policy. First, the creative industries in developing countries have different characteristics from developed countries: they are often unrelated to intellectual property and mostly craft-based. Hence, Indonesia's creative industry is dominated by traditional crafts. Second, the characteristics of the regional economy and technology in Indonesia are still experiencing industrialization. Thus, entrepreneurial activity in such a creative industry context appears as a necessity and not as an opportunity. Indonesia is suitable for the creative industry because it is categorized as an underdeveloped industrial base with lower-middle and lower GNI per capita levels in $2014(\$ 3,630)$.

Moreover, Indonesia consists of more than 13,000 islands and hundreds of various ethnicities and languages. This cultural heritage and diversity, in addition to a vast household market (240 million), can create more opportunities for the creative industry to explore. Due to its significant potential, the Indonesian Ministry of Tourism and Creative Economy has launched the Creative Economy Development Plan 2025 through a blueprint for long-term development.

The development of creative industries in Indonesia consists of 16 sub-sectors. Sixteen sub-sectors of the creative economy is the development of applications and games, architecture and interior design, visual communication design, product design, fashion, film, video animation, photography, crafts, food, music, publishing, advertising, performing arts, visual arts, television, and radio. Creative industries supporting the tourism industry in Indonesia is a creative form of handicraft business that aims to develop the local culture. They attract tourists through the sale of handicraft products. One of them is handicraft embroidery, which is then applied to souvenir products such as sandals, souvenirs, leather hats, religious supplies, shoes, and bags.

The development of the creative industry in East Java is influenced by the character and culture of Javanese people who prefer to be entrepreneurs (to be entrepreneurs) than to work for others Al-Shimari et al., (2019). To support this argument, Jodi et al., (2019) examined the role of local Javanese culture, which is still thick with traditional leadership models in local society. Regarding the concept of Cultural organization, there are still many opinions from SME owners who think that doing business is enough to fulfill their daily needs, so there is no need to make innovative and leading efforts to improve company performance. Given that this research is focused on SMEs in the creative industry, the sensitivity to innovation is higher.

Because SMEs provide handcrafted products, entrepreneurs cannot replace the appliance with machinery and modern technology because they would reduce the value of the product. SMEs must offer unique, handmade products that will connect with traditional and cultural values. From organizational culture, employees who are not able to understand what they have to achieve generally still depend on the wishes of their owners or company leaders.

The government provides a wide range of training to encourage SME innovation in East Java; the SME manager then also realize that it is imperative to enhance innovation company that ultimately affect the performance of SMEs. Research urgency stems from whether the innovation efforts, including government support in line with the entrepreneurial orientation and organizational culture to improve SME's innovation. In short, it is essential to investigate whether stimulation of innovation activity organizations conducted on SMEs today has been effective in fostering the performance of SMEs in East Java. Despite the increased understanding of the need for innovation activities, studies examining the effectiveness is still limited to reinforce the organization's performance in the creative industries supporting tourism SMEs. This study aims to analyze the impact of organizational culture and entrepreneurial orientation on organizational innovation and organizational performance in SMEs. 


\section{LITERATURE REVIEW}

In previous studies, several researchers have defined entrepreneurship in several approaches, but all have the same meaning. According to Tassabehji et al. (2019), an entrepreneur is someone who creates a business, and they describe an entrepreneur as someone who starts an innovation, a new product. , and find new markets. Entrepreneurship is described in terms of creativity, innovation, risk-taking, flexibility, and growth.

Entrepreneurial orientation is related to behavior, practices, styles, decision-making, and processes that influence organizations to enter new markets or existing products and services (Hadryś-Nowak, 2018). Based on Covin \& Wales (2011), previous research shows that entrepreneurial orientation has three dimensions, namely, innovation, proactivity, and risk-taking. The first dimension of entrepreneurial orientation is about the practice and the provision of support for innovation, creative processes, and enhancement of new ideas through experimentation (Lumpkin \& Dess, 1996).

The second dimension is proactive. Proactive refers to the process, how we seek and get opportunities that may relate to the present. The introduction of new products and brands and how to remove products in a mature and declining life cycle stage (Ketut Santra, 2018). This dimension concerns the importance of the initiative in entrepreneurship. An organization can create a competitive increase by predicting changes in interest in the future (Lumpkin \& Dess, 1996).

Furthermore, they become active participants to form their environment (Amin et al., 2016). The third dimension, risk-taking, is used to explain the uncertainty that follows entrepreneurial behavior. Entrepreneurial behavior tries to be involved in providing a portion of the resources to achieve specific project goals.

Growth is considered an indicator of organizational performance and is associated with achieving financial goals. Company turnover is the measure most often seen as the value of growth; however, some researchers rate growth, as seen in the number of employees as a measure. Interconnection between these two growth indicators in the SME context, due to the visibility and simplicity of the organization. There are many definitions related to this SME, but the main criteria are related to the number of employees, sales, and level of investment. Some categorize SMEs as having employees of no more than 250 employees (Ahn, Hyun, \& Kim, 2016).

Two essential aspects from the perspective of organizational performance in management strategy are the constituents for whom the organization performs and its dimensions, which must be calculated. Aarstad et al. (2015) categorize three factors that will affect the performance of SME organizations. The person who founded SME and the main resources that are presented for the creation of the SME.

Personal characteristics of SME owners can contribute to the company's growth, such as motivation, education, ownership/management experience, number of founders, ethnicity/race, age, and gender. For example, motivation can influence the strategic choices made by SME owners, and educated and experienced SME owners usually set up an organization in the discipline they have been educated on and are likely to find better growthrelated opportunities. Furthermore, if there are more than one UMKM owner, it leads to a diversity of experiences, skills, and resources that are mutually compatible (Ketut Santra, 2018).

The factor for the growth of an SME is the characteristics of the organization, which are linked to the decisions made when starting a business. Several factors include age, sector, location, size, and form of ownership. Businesses operating in one sector may grow faster than others. There are benefits and limitations for organizations located in urban and rural areas. The third influencing factor that contributes is business practices/management strategies, which correlate with managerial actions in an organization.

Entrepreneurial orientation is measured as a behavioral procedure that operates at a firm level. If entrepreneurial orientation tends to lead to innovation, then companies will follow and manage innovation in their activities compared to companies where entrepreneurs are less innovative and avoid risk and perform better than competitors. Entrepreneurial 
orientation can drive the innovation process. So much literature emphasizes the positive effects and relationship between entrepreneurial orientation and innovation (Prima Lita, Fitriana Faisal, \& Meuthia, 2020)

According to Lumpkin \& Dess (1996), entrepreneurial orientation refers to the trend of companies that are innovative, proactive, and prone to business risks. Besides, Ahman et al. (2020) argued that an entrepreneurial orientation reflects:

H1. Entrepreneurial orientation positively, significantly influences innovation;

H2. Entrepreneurial orientation positively, significantly influences Risk Taking;

H3. Entrepreneurial orientation positively, significantly influences proactive.

\section{METHODS OF RESEARCH}

This research is a descriptive quantitative look at the facts on the ground. The variables used in this study consisted of independent variables of entrepreneurial orientation and business performance in small and medium enterprises (UKM). Data collected through a survey. Research location in Bangli, East Java, Indonesia. The population of this research is all business actors in the creative embroidery industry in Bangil, which can be 100 (one hundred) people, both men, and women, with different ages, education levels, business scales, and businesses. Analyst research using PLS-SEM.

\section{RESULTS AND DISCUSSION}

Respondents in this study were all business actors in the creative embroidery industry in Bangil, totaling 100 (one hundred) people, both men, and women, with different ages, education levels, business scales, and length of business. This research was conducted by meeting with business actors to distribute questionnaires and some of them conducting interviews. This is done in order to develop information, to obtain background information on starting a business and its development strategy.

The results of the research regarding the characteristics of the respondents were seen from gender, age, latest level of education, business scale, and length of business, and it can be concluded that the embroidery business actors were mostly women, namely 78 people (78\%). There are several reasons why women dominate this type of business. First, because embroidery is considered a home business and needs patience and a touch of beauty, all of which is reflected in the soul of a woman. Second, this embroidery business has initially been only a side business to fill spare time for women who only act as housewives.

In terms of age characteristics, the age actors of this embroidery business are mostly those who are elderly. From the results of the interview with Mrs. Dewi Fathonah, the owner of Fath Embroidery, those who are fresh graduated are more interested in getting income instantly, namely by working in factories that are widely spread in Bangil. PIER (Pasuruan Industrial Estate Rembang) is an industrial area in the Pasuruan Regency, precisely in the Bangil area, Rembang District, which has a land area of 556 hectares. In this pier area, there are more than 90 companies that can accommodate total employment of 15,000 people or more. PIER's location, which is very close to the Bangil Embroidery center, is the reason why young people in Bangil are not interested in following in the footsteps of their predecessors by opening a business in the embroidery field.

Table 1 - Respondent profiles

\begin{tabular}{|c|c|c|c|}
\hline Category & Description & Frequency & $(\%)$ \\
\hline \multirow{2}{*}{ Gender } & Male & 22 & 22 \\
\cline { 2 - 4 } & Female & 78 & 78 \\
\hline \multirow{3}{*}{ Age (years) } & $25-35$ & 12 & 12 \\
\cline { 2 - 4 } & $36-55$ & 63 & 63 \\
\cline { 2 - 4 } & $>56$ & 25 & 25 \\
\hline \multirow{3}{*}{ Occupation } & Elementary schol & 0 & 4 \\
\cline { 2 - 4 } & Junior high school & 79 & 79 \\
\cline { 2 - 4 } & Senior high school & 17 & 17 \\
\cline { 2 - 4 } & College & 79 & 0 \\
\cline { 2 - 4 }
\end{tabular}


The results of the internal model analysis (Structural Model) state that the path coefficient of the Innovative variable to the Business Performance variable is 0.316 and significant with a p-value (0.005) less than 0.05 . On the other hand, the ability to take risks and be proactive is not significant, with $p$-values of 0.359 and 0.217 , respectively, which are far above 0.05 .

Table 2 - Result of Hypotheses Testing

\begin{tabular}{|c|c|c|c|c|}
\hline $\mathrm{n} / \mathrm{n}$ & Influence Coefficient & $\mathrm{t}$-value & $\mathrm{p}$-value & Information \\
\hline Innovative $\rightarrow$ business peformance & 0.316 & 2.842 & 0.005 & Significant \\
\hline Risk $\rightarrow$ business peformance & -0.137 & 0.919 & 0.359 & Not significant \\
\hline Proactive $\rightarrow$ business peformance & 0.162 & 1.236 & 0.217 & Not significant \\
\hline
\end{tabular}

From the results of data processing carried out on Entrepreneurship Orientation, which is explained by the innovation variable, the ability to take risks, and being proactive, it produces different effects on the dependent variable on business performance. The innovation variable has a significant influence on the business performance variable, while the risk-taking and proactive ability variable does not have a significant effect.

Entrepreneurship orientation itself as an independent variable simultaneously, in this study, does not have a significant effect on the dependent variable, business performance. With an R Square value of 0.139 (under 0.19 ), the relationship between the Entrepreneurial Orientation variable and the business performance variable is weak. So it can be concluded that other variables influence Entrepreneurship Orientation so that it can have a significant effect on business performance. The variables included in the PLS-SEM model are less able to explain business performance. Other variables are thought to affect business performance, but that is not included in the analysis, namely the business environment, for example, cultural factors, family, and socio-economic structure. Thus, it can be said that entrepreneurial orientation will have a direct and indirect impact on company performance. Because it depends on different environments and cultures (Zahra, 2008; Kellermanns, Eddleston, Barnet \& Pearson, 2008), through deep qualitative data mining, in this study, cultural factors have a significant influence on business performance in several categories of business behavior. People from different cultures can have different work ethics, and perceptions of the businesses carried out by men or women.

\section{CONCLUSION AND SUGGESTIONS}

This study examines the effect of entrepreneurial orientation on business performance in MSMEs in East Java, Indonesia, involving 100 respondents who drive the UMKM. The innovation variable has a significant influence on the business performance variable, while the risk-taking and proactive ability variable does not have a significant effect.

The variables included in the PLS-SEM model are less able to explain business performance. There are other variables thought to affect business performance, but that is not included in the analysis, namely the business environment, for example, cultural factors, family, and socio-economic structure. Thus, it can be said that entrepreneurial orientation will have a direct and indirect impact on company performance because it depends on different environments and cultures. Through in-depth qualitative data mining, in this study, cultural factors have a significant influence on business performance in several categories of business behavior. People from different cultures can have different work ethics, and perceptions of the businesses carried out by men or women.

\section{REFERENCES}

1. Aarstad, J., Ness, H., \& Haugland, S. A. (2015). Innovation, uncertainty, and inter-firm shortcut ties in a tourism destination context. Tourism Management, 48(1), 354-361. https://doi.org/10.1016/j.tourman.2014.12.005

2. Ahman, E., Machmud, A., Sumawidjadja, R., \& Herlinawati, E. (2020). Model of the 
competitive advantage of creative industries in Indonesia based on helix quadruple, creativity and innovation capability. International Journal of Innovation, Creativity and
Change,
11(8),
$516-532$.
Retrieved
from

https://www.scopus.com/inward/record.uri?eid=2-s2.0-

85081911139\&partnerID=40\&md5=f8adaaf41680e4ccd2edfefdf500951d

3. Ahn, Y.-J., Hyun, S. S., \& Kim, I. (2016). City Residents' Perception of MICE City Brand Orientation and Their Brand Citizenship Behavior: A Case Study of Busan, South Korea. Asia Pacific Journal of Tourism Research, 21(3), 328-353. https://doi.org/10.1080/10941665.2015.1050422

4. Al-Shimari, K. K. J., Hamzh, H. K., \& Alktrani, S. H. (2019). Tourism, creative industries and exports sustainability: An international comparative study. African Journal of Hospitality, Tourism and Leisure, 8(5). Retrieved from https://www.scopus.com/inward/record.uri?eid=2-s2.085074411640\&partnerID=40\&md5=36bba163095cff68b40a04f049254594

5. Amin, M., Thurasamy, R., Aldakhil, A. M., \& Kaswuri, A. H. B. (2016). The effect of market orientation as a mediating variable in the relationship between entrepreneurial orientation and SMEs performance. Nankai Business Review International, 7(1), 39-59. https://doi.org/10.1108/NBRI-08-2015-0019

6. Covin, J. G., \& Wales, W. J. (2011). The Measurement of Entrepreneurial Orientation. Entrepreneurship Theory and Practice, (540), 1-26. https://doi.org/10.1111/j.15406520.2010.00432.x

7. Games, D. (2019). Can sme benefit from innovation in an emerging market economy? Academy of Entrepreneurship Journal, 25(1). Retrieved from https://www.scopus.com/inward/record.uri?eid=2-s2.0-

85067080437\&partnerID=40\&md5=499cbacd2119f5352a125749b7857f81

8. Hadryś-Nowak, A. (2018). Family entrepreneurship orientation in family owned SMEs: A key resource for internationalization? Entrepreneurial Business and Economics Review, 6(2), 153-169. https://doi.org/10.15678/EBER.2018.060208

9. Helmy, I., Adawiyah, W. R., \& Banani, A. (2019). Linking psychological empowerment, knowledge sharing, and employees' innovative behavior in Indonesian SMEs. Journal of Behavioral Science, 14(2), 66-79. Retrieved from https://www.scopus.com/inward/record.uri?eid=2-s2.0-

85076017457\&partnerID=40\&md5=57efcdc9857d52b773e8e28e22622f5f

10. Ikhsan, K., Almahendra, R., \& Budiarto, T. (2017). Contextual ambidexterity in SMEs in Indonesia: A study on how it mediates organizational culture and firm performance and how market dynamism influences its role on firm. International Journal of Business and Society, 18(S2), 369-390. Retrieved from https://www.scopus.com/inward/record.uri?eid=2-s2.085036595868\&partnerlD=40\&md5=3cbaea006867ead63a52eba3031396a2

11. Imanto, Y., Prijadi, R., \& Kusumastuti, R. D. (2019). Innovation ecosystem for SMEs in the creative industry. International Journal of Business, 24(4), 345-368. Retrieved from https://www.scopus.com/inward/record.uri?eid=2-s2.0-

85073113428\&partnerID=40\&md5=d1310fa764feb33fd5e0e24fa55eb322

12. Jodi, N. S., Sudjadi, A., \& Anggraeni, A. I. (2019). The role of creativity in forming innovative behaviours of creative industrial workers. International Journal of Innovation, Creativity and Change, 9(11), 166-178. Retrieved from https://www.scopus.com/inward/record.uri?eid=2-s2.085078904907\&partnerID=40\&md5=09fe33d954d0fef3246a3836f87308b6

13. Ketut Santra, I. (2018). Entrepreneurial orientation and marketing performance of budget hotel smes in bali island. International Journal of Entrepreneurship, 22(4). Retrieved from https://www.scopus.com/inward/record.uri?eid=2-s2.085060875171\&partnerlD=40\&md5=6dedf7a8053d40ed9fa5f362db7dfbd5

14. Lumpkin, G. ., \& Dess, G. G. (1996). Clarifying the Entrepreneurial Orientation Construct and Linking It to Performance. The Academy of Management Review, 21(1), 135-172.

15. Machmud, A., \& Sumawidjaja, R. N. (2020). The influence of co-creation on creative 
industry performance in Indonesia. WSEAS Transactions on Environment and Development, 16, 316-323. https://doi.org/10.37394/232015.2020.16.33

16. Ng, H. S., \& Kee, D. M. H. (2018). The core competence of successful owner-managed SMEs. Management Decision, 56(1), 252-272. https://doi.org/10.1108/MD-12-2016-0877

17. Prima Lita, R., Fitriana Faisal, R., \& Meuthia, M. (2020). Enhancing small and medium enterprises performance through innovation in Indonesia: A framework for creative industries supporting tourism. Journal of Hospitality and Tourism Technology, 11(1), 155176. https://doi.org/10.1108/JHTT-11-2017-0124

18. Richardson, N. (2019). Corporate social responsibility or sustainability in music festivals. International Journal of Organizational Analysis, 27(5), 1257-1273. https://doi.org/10.1108/IJOA-03-2018-1368

19. Rofaida, R., Suryana, \& Yuliawati, A. K. (2019). Developing organisational capacity in the creative industry to improve business performance. International Journal of Innovation, Creativity and Change, 9(5), 209-227. Retrieved from https://www.scopus.com/inward/record.uri?eid=2-s2.085078252304\&partner ID=40\&md5=6dc8212e431480d2568deac3f4055330

20. Siregar, J. J., \& Aryanti Wardaya Puspokusumo, R. A. (2020). Design and development of knowledge management system in the small and medium-scale enterprises base on mobile apps (Smes at indonesia). (S. F., M. F., \& G. N., Eds.). Computer Science Department, School of Computer Science, Bina Nusantara University, Jakarta, 11480, Indonesia: Springer. https://doi.org/10.1007/978-3-030-33582-3_96

21. Tassabehji, R., Mishra, J. L., \& Dominguez-Péry, C. (2019). Knowledge sharing for innovation performance improvement in micro/SMEs: an insight from the creative sector. Production Planning and Control, 30(10-12), 935-950. https://doi.org/10.1080/09537287.2019.1582101

22. Wiklund, J., \& Shepherd, D. (2005). Entrepreneurial orientation and small business performance: a configurational approach, 20, 71-91. https://doi.org/10.1016/j.jbusvent.2004.01.001

23. Zheng, P., \& Callaghan, V. (2018). How Chinese SMEs Innovate Using 'Diegetic Innovation Templating' - The stimulating role of Sci-Fi and fantasy. Futures, 95, 98-117. https://doi.org/10.1016/j.futures.2017.10.005 